\title{
Economic Empowerment of Islamic Student Throught Optional Course Learning in Boarding School for Harmonization and Preventing Negative Stigma
}

\author{
Adhi Iman Sulaiman ${ }^{1}$, Bambang Suswanto ${ }^{2} \&$ Masrukin $^{3}$ \\ ${ }^{1}$ Department of Communication Science, FISIP Jenderal Soedirman University, Indonesia \\ ${ }^{2}$ Department of Political Science, FISIP Jenderal Soedirman University, Indonesia \\ ${ }^{3}$ Department of Sociology, FISIP Jenderal Soedirman University, Indonesia \\ Correspondence: Adhi Iman Sulaiman, Kampus Grendeng No 1 Purwokerto Central Java 53122, Indonesia. Tel: \\ 62-8163-529-4. E-mail: adhi.2005unsoed@gmail.com
}

Received: August 22, 2018; Accepted: September 26, 2018; Published: October 1, 2018

The research is financed by Institute for Research and Community Service of Jenderal Soedirman University and Ministry of Research, Technology and Higher Education of the Republic of Indonesia.

\begin{abstract}
The research aims to design economic empowerment model of santri in pesantren education. The study used Participatory Rural Appration method and purposive informant selection consisting of pesantren board, teacher, santri and community. Data ware collected through documentation analysis, direct observation, interviews, and Participatory Decision Making. The location of the study was determined at pesantren of Al-Muttaqin in Cirebon, West Java and Darusy Syahadah in Boyolali, Central Java. The study was analyzed by PRA through triangulation to find the diversity of difference and similarity as well as data verification. The results show (1) Pesantren has motivation and potency to make economic institution through empowerment activity of santri like horticulture cultivation, fish and goat farm, retail and also cooperation. (2) Empowerment activities, especially through education programs, can provide students with entrepreneurial skills, independence and welfare, create harmonization with the community and anticipate the negative stigma of exclusive, closed and radical of pesantren.
\end{abstract}

Keywords: economic empowerment, entrepreneurship, harmonization, Islamic boarding school, optional course

\section{Introduction}

Islamic boarding school (Pesantren) is a social and educational institution that has long been present and played a role in the community of Indonesian society and according to Thahir (2014) the Pesantren is one of the educational institutions has recognized a more influence in educational development, it also could be alternative for education problems solving. It becomes part of life process that can not be separated between world affairs and affairs akherat associated with the faith from birth, life activity to the death. Pesantren becomes a social and educational institution that integrates and develops along with the life of the people, especially in rural areas that become a valuable heritage as local wisdom. As according to Fajarini (2014) local wisdom is a life view and science and life strategy embodied in community activities to answer various problems in the fulfillment of needs. Cahyad (2017) dan Thoyyib (2018) states pesantren as an indigenous educational institution that has long been born and developed along with social, economic and cultural life in society.

Pesantren that was once an informal and non-formal education, is always said to be a traditional educational institution, but its role remains as a reformer agent that gives life, especially for people who can not continue formal education, in remote or isolated areas, and alternative places to form and improve the mental and moral characteristics to be better or good morals (akhlaqulkarimah). The subsequent development of pesantren became a formal educational institution registered with government standard from education system, process, curriculum, educator, facility to graduation.

Furthermore there is a boarding school that combines formal education and an informal boarding school with a system of lodge or lodge Islamic students (santri) who called modern pesantren. Yaqin (2012), Mumtahanah (2015) and Hadiningrum (2017) confirmed that pesantren was originally an informal social institution, but the subsequent 
development of many pesantren became formal educational institutions or often called modern pesantren and there were also combinaion of formal and informal education system.

There are various problems that are faced especially for pesantren educational institutions that are still considered traditional, namely the negative stigma as social institutions and education places for children who have problems or naughty children who can not be overcome by the family and from poor families, so that boarding schools become alternative institutions or not as a primary goal. Even with the many bombings and terrorism incidents, pesantren is considered to be an educational institution that generates radical understanding and a terrorist nest that precisely causes denial of religion such as intolerance, excessive fanaticism and hostility. According to Azra (1999) radicalism as a form of revivalism as an understanding of Islam that is oriented and applied the belief and faith only to himself (inward oriented) and the form of radicalism that tends to have outward oriented by acts of violence that is often called fundamentalism.

Radicalism grows on the understanding and religious fanaticism that is not balanced by humanistic, fraternal, empathy, tolerance, mutual help, awareness of the common life to give merit and become grace (rahmatan) for the whole of nature. Radicalism raises the nature of hatred, enmity and war against others who are considered unfamiliar or one ideology, beliefs and beliefs. Radicalism is also a form of resentment, frustration, jealousy, and social, political and economic gaps, so it is easily provoked to engage in hostile conflict and choose violent of struggling earnestly (jihad), murder and bombing as a shortcut for the reason of afterlife (akherat) happiness. According to Thoyyib (2018) the concept of jihad should not only be understood as the context of war against the enemy with the pretext of being the best way to die in Allah's path as the highest and noble ideals, so that the concept of jihad has the potential to be influenced by the violent doctrine used as the basis for terrorists in Indonesia . Though the concept of jihad as a form against the lust and do good and forbid the evils (amar ma'ruf nahi mungkar), and against the enemy with in God's way of struggling earnestly (jihad fi sabilillah). Abdullah (2016) and Alfanani (2016) states that radicalism rejects the process of dialogue, persuasive approaches and take a moderate path, whereas in Islam the concept of jihad is a form of endeavor in earnest, mentally and thoughtfully to create justice and peace in society, because if there is an element of violence it is contrary to the concept of mercy to all the worlds (rahmatan lil'alaim). Rodin (2016) declares the jihad's character to strive to achieve a goal of creating welfare rather than warfare, for warfare or Qital is temporal and conditional and emergency as the last resort after the path of peace.

Thus, to anticipate radicalism as a negative stigma for pesantren, it can be done by making pesantren not only as a social institution and religious education, but also become an economic education institution that can develop the potential and resources of environment, economy and society so that pesantren is not only doing religious activities such as da'wah education, but also to do education and charity worship (amaliyah) activities that can benefit santri, pesantren and the surrounding community. Pesantrens will be educational institutions that also teach and practice about the concept of economic empowerment, establishment and development of business institutions such as mini markets, workshops, sharia cooperatives, sharia financial institutions, agriculture, animal husbandry and fisheries. So that pesantren no only shape and pass ustadz to continue religious education, but also create entrepreneur, business group and economic institution that is useful both for santri, graduates, pesantren and society. Pesantren will have characteristic as agriculture education community and livestock pesantren, sharia economy marketing. This can be done by incorporating the subjects of sharia economy, business management, entrepreneurship, cooperatives and economic empowerment in the curriculum of pesantren both as an introduction or general subjects, and special lesson, stewardship or specialization, and local content. Because according to Asrori (2015) one of the causes of the emergence of radicalism due to poverty or powerlessness in the face of economic life, thus there needs to be a welfare approach rather than security. So to realize the welfare requires an empowerment program, according to Adams (2003) and Suhartini et al. (2005) empowerment is a medium that helps individuals, communities to be able of environment menegement and can achieve the expected goals, so as to work and help hemseves and others to maximize the quality of life. According to Susmono and Hidayat (2010) community empowerment is a process of providing opportunities and giving people the power to participate, have knowledge, skills and skills.

So pesantren will play a more open role to interact with the wider community in the various needs of life and no longer considered closed or exclusive, and radical. It can prevent economic inequality and social and economic conflicts. Designing the development of pesantren is determined by the reformers who are the kiyai, ulama and ustadz who become role models, opinion leaders and life consultants for the community both religious, moral, spiritual, social and economic affairs as well as political affairs. Pesantren with such reformers can play a role to counteract the mistakes of radical understanding and the meaning of jihad in Islam. Pesantrens should receive concrete support from government, academia and private institutions by collaborating to educate pesantren schools 
that can fully support the development of human resources mentally, spiritually, morally, science and skills, social development such as tolerance, empathy, solidarity and harmony and unity, as well as economic development such as creating jobs, shaping and developing corporate, economic institutions, good welfare for santri, pesantren and surrounding communities.

Based on that the researcher is interested to analyze and make model of economic empowerment as education program of boarding school in anticipation of radicalism.

\section{Method}

The research uses Participatory Rural Appraisal (PRA) methodology which provides an opportunity for the community to identify and analyze the conditions and situations in planning and implementing participatory program activities (Mikkelsen 2011). The location of the study was determined at the Al-Muttaqin boarding school in Beber, Cirebon district, West Java and Darusy Syahadah pesantren in Simo, Boyolali district, Central Java.

Data collection is taken through document analysis, direct observation, open interviews, and Focus Group Discussion (FGD) activities to understand the attitude and behavior of the community in a focused and dialogical way, and implement Participatory Decision Making (PDM). The research informant is chosen purposively, consisting of owner and board of boarding school, ustadz (teacher) and santri as management of business group and Cooperative of Pondok Pessantren (Kopontren), society figure around pesantren.

This study then analyzed PRA research data through triangulation to look for diversity and similarity, then carried out investigations directly from and with community or community (Syahyuti 2006).

\section{Results and Discussion}

\subsection{Economic Empowerment Potention in Pesantren}

Pesantren of Al Muttaqin is located on the highway between Cirebon and Kuningan, precisely in the area of Kondangsari Beber Cirebon West Java, as a modern educational institution at junior high school level. It applies educational process with a boarding school system that has a 24-hour parenting pattern that aims santri can receive and apply science better. It has been established since 2004 which took the role of preparing the generation of "Alim Muttaqi" with the pattern of "Tarbiyah Islamiyah" that combines the curriculum of the national education and boarding school with the hope of appropriate vision to create a generation full of achievement, devoted, independent, creative and actively pledge to uphold Islamic values in the community. Its educational curriculum has local content of pesantren especially Aqidah, Fiqh, Tafsir, Akhlak, Hadith, Tarikh Islam, and Arabic. In addition the extracurricular activities consisted of Arabic, English, and Indonesian speech (Muhadhoroh), scouting (Kasafa), Tahfidzul Qur'an and martial arts training.

While Darusy Syaadah Boyolali pesantren started from Madrasah Diniyah or elementary school in 1994, the next development opened the level of Senior High School (SLTA) and up to Ma'had Aly (high school) level. The background set up a boarding school to print on Da'i and Mu'allim in the midst of the progress of the world of science and technology. Ma'had Aly is a high-level institution of religious education that organizes a scholarly cadre education with a major study of the classical (Turast) and contemporary (Ashry) books based on Islamic teachings. The curriculum is structured based on interdisciplinary approaches such as figh, ushul-fiqh, tafseer, hadith, and hadith science combined with the use of the Mu'tabarah books in pesantren tradition. Ma'had Aly has a study program namely Aqidah, Fiqh, Siroh An-Nabawiyah, Hadith, Tafsir and Arabic.

Based on the results of in-depth interviews, discussions and direct observations, the boarding school of Al Muttaqin Cirebon and Darusy Syahadah Boyolali have similarities in maintaining the istiqomah in the Islamic education on the basis of entrepreneurship, Islamic economy or sharia economy, economic empowerment, business management and sharia cooperative, sharia finance management that are lessons that has been offered and learned by other schools that are not pesantren. However, in the process of dialogue and discussion the researcher still provides another perspective that the educational content in pesantren still needs to teach about economic empowerment and entrepreneurship to santri, pesantren and community. Because pesantren is not only producing ustadz, ustadzah and kiyai who are competent in religious field but also there are competent in Islamic economic field either as entrepreneur, consultant and economist of Islam.

They can even be an Islamic economic reformer agents that can give benefit especially and society in general to help the people and society. Because reality shows that Muslims are still weak in terms of economic life meaning they have not been as a leading role in the economic field such as the lack of the role of Muslims in business, trade and small group business. The dependence of Muslims in the economy ranging from the downstream of the spirit and awareness of business, ownership of venture capital, production processes, marketing and business networks among Muslims. Islam in the economic field is still exclusively oriented only to its own community, has not 
established a network of business either to fellow Muslims and to the public at large. Although now a lot of banking and insurance services are starting to adopt innovation by using sharia label, but it is only as a strategy to gain a lot of muslim customers, clients, creditors and debtors Muslims in Indonesia.

Pesantren of Darusy Syahadah already has some business units and growing rapidly such as building stores, printing books, photocopy services, stalls and Cooperatives, even pioneering goat farming business. So Pesantren of Darusy Syahadah has high awareness and spirit to do economic effort in assisting economics and prosperity of board and the boarding school. But they have not put enterprenership into the content of the lesson either the nature of the introductory lessons, lessons of choice or additional lessons or local content (look for the type of lesson). The business process is done directly in the offer for the practice for the final level students who will graduate and are interested in serving in the field of pesantren business. The economic business potential of Darusy Syahadah boarding school is very large because it have 1200 santri and with an area for empowerment programs of 4 hectare, so the recommended economic empowerment program are for the establishment of fish, goat and cattle, horticulture and even business. Then Darusy Shahadah has the number of alumni that can be used as human resources, business capital and marketing network for the economic business of boarding. Utilization of land for economic business can be used as parktikum program, dedication and empowerment of santri in pesantren.

Darusy Syahadah was parties agreed to create empowerment programs and implement them, which are extension and training activities on institutional development and management of cooperatives as the holding company of business units owned by pesantren. Implementation of the devotion will involve the management of cooperatives, head of business units and students who have interest and as a cadre of cooperative and business board in pesantren Further empowerment of goat farming that will be oriented to meet the needs of the sacrifice in the Eid al-Adha moment especially for the pesantren and the surrounding community. Then for economical subjects such as Muslim entrepreneurship, Islamic economics or sharia, business management and sharia finance, it becomes the consideration of the boarding school board to become a special subject both mandatory and selective, as it relates to the availability of teacher who master the field.

While Pesantren of Al Muttaqin Cirebon, once had a business unit by opening a grocery store and kiosk rental on the edge of boarding schools, but they did not coninue the business, due to difficulties to find a manager who can totally manage it. Al Muttaqin boarding school only has a canteen business unit and a grocery store that are oriented to meet the internal needs of students only, so it has not developed into a larger economic business. Obstacle that has been faced i.e human resources who will manage the business both grocery store and Cooperation are still done by ustadz who have limited time due to the duty and obligation to teach. So that busenisses are not managed properly, the time available for services is only the spare time after after teaching. Then the leader of the boarding school actually has the desire and enthusiasm to include the Islamic economic material in the subjects including the establishment and development of economic enterprises in the pesantren, but they have not had enough teachers so that they must bring the expert or master the field.

Al Muttaqin boarding school has the potential with the width of land 1 hectare and located in a strategic location that is on the edge of the highway Cirebon and Kuningan lines. The land can be used as a medium for economic empowerment for students, Asatirin ustadz and his family and alumni. The potential for making horticultural and hydroponic vegetable crops can be done because it fits in the highlands at least to meet the needs of the pesantren. Limited human resources to form and develop economic businesses both cooperatives, gocery store, and cultivation of horticulture can be done by forming a special management that manages the type of business, especially the wives of ustadz who are not teaching staffs or housewifes, in addition from the alumnae who have not worked yet.

It is recommended to put Islamic economics subjects on entrepreneurship, Islamic economic management (sharia), and shariah cooperatives into lessons even if the santri are still at the level of Tsanawiyah education or Junior High School. Because it is very important to introduce and form the spirit, awareness and basic skills for the generation of Muslims as a foundation that will equip santri. So the pesantren will have plans to seek and bring in specialized teaching staffs mastered in Islamic economics such as entrepreneurship, sharia economy management and Sharia Cooperative as additional subjects and local content.

The empowerment of Islamic economics through the creation of program activities ranging from counseling, training, mentoring and partnerships, including incorporating subject such as Islamic entrepreneurship, sharia business management and Sharia Cooperative as medium of interaction and publication to counter negative stigma of pesantren as a closed institution, radical and nest of terrorists. This stigma occur because pesantren tends to be a social and educational institution focused only on religious studies and dakwah, lacks of the desire to increase the focus of activities and learning on Islamic economics or sharia business management. Media of pesantren 
interaction is still limited that only manages religious education field, but still lacks of amaliyah interaction of econimocal media. Hartono (2012), Rahmawati (2016) and Kusnadi et al. (2017) state that pesantren can adapt and develop dynamically because they have a culture that demands the discipline and independence of santri and the pattern of social interaction related to academic activities. Furhermore the economic empowerment in pesantren education can create a pious individual that can be useful for the benefit of development. According to Aswira (2013) and Abdurrahman (2016) development has an impact on changes in human behavior, will result in a soulful person who always wants to build, as well as has the skills and knowledge needed to carry out the desired development.

Hence doing the economic empowerment and putting the subjects of Islamic economics in the pesantren and with economic business activities can be a medium of $d a^{\prime}$ wah amaliyaah in addition to create a welfare for students and alumni also for the surrounding community. Pesantren and santri with economic empowerment and economic activity will strengthen positive image and strong ties with the public so that the negative stigma that is currently identified with pesantren will be answered. So far, pesantren seems exclusive and closed and does not blend with the surrounding community, because it lacks the media of interaction with the wider community besides the santri family, the most effective media such as the media of economic empowerment and economic business activities that can be formed and developed in pesantren, furher the next phase involves the alumni and the surrounding community.

Pesantren still has the idealism and culture of preserving, strengthening and developing syiar Islam with tarbiyyah and shariah, but can also play a role in amaliyyah activities in the economic field. So the development of pesantren will be formed into agricultural pesantren, Islamic economic of pesantren, and pesantren agribusiness. Nilan (2009), Das et al. (2016) and Purnamasari (2016) states that the education of pesantren is relevant retaining its characteristics to stem moral damages with spirituality, although it is not impossible to adapt to the demands of global development. Meylaz (2014) and Ikhwan (2017) states that boarding school can combine two traditional and modern education system including in boarding school management, in order to have its own unique and interesting characteristic.

The economic empowerment of pesantren and the content of subjects and interests of extracurricular activities can be designed by spreading the questionnaires to the santri and the ustadz. Then the questionnaire results are identified and analyzed to be used as study course learning or dialogue and consideration of program making. The next stage is to organize dialogue forums to discuss the results of the questionnaire so that economic empowerment programs, interests and economic subjects will be designed in accordance with the aspirations, human resource potential, natural resources and economic resources of students and pesantren. Hamdani (2012) states the process of counseling students to know the motives, interests and characteristics or potential both social and economic to design the future of santri both education and careers. Muharom (2015) and Hidayat (2016) states that the role of community relations teams in pesantren can be a mediator and facilitator with outsiders, both prospective students and parents of santri and surrounding communities to improve the reputation or image of pesantren that sometimes have negative stigma.

The process of the dialogue is then discussed and can involve ustadz and alumni to create and implement the empowerment program and the Islamic economic curriculum to realize. As according to Muklasin (2016) the making, determining and realization of educational programs and activities in pesantren are carried out in a deliberation to accommodate all the proposals and needs of all parties. Isnaini (2013) and Hidayat (2016) said that to create dynamics, effective learning process and development of pesantren, hence required an open communication media between kiyai and santri. Servaes (1999) states empowerment has a relationship with participation to make collective decisions at all levels of society to help themselves and define their own goals.

Pesantren can also involve colleges and local governments in implementing economic empowerment programs including cooperation with other pesantren that have developed and advanced economic activities. The obstacles that are still faced is the lack of willingness of the boarding school to be able to cooperate with other colleges and pesantren, which can actually be proposed cooperation. The local and central government can also proactively initiate to have and run the pesantren economic empowerment program, not only monitoring and evaluating the activities of pesantren activities in terms of religious education, but also in terms of consideration of suspicion of the negative stigma that is formed. Pesantren should be approached and made partners for development by the government, which has programs and budgets and responsibilities to involve all parties in the development process and prosper the community. It includes colleges to care and give empathy for the economic empowerment of pesantren, especially those who get negative stigma with community service program, research, practicum and apprenticeship, and the thematic program of Community Service Program. According to Mursalin and Katsir (2010), Perdana (2015), pesantren as traditional educational institutions requires greater attention especially from 
other parties such as government compared with integrated or modern educational institutions, especially in the management of institutional development of education.

If there is no sense of empathy, solidarity and understanding from government and higher education to run the economic empowerment program in pesantren, the negative stigma will continue to be attached, pesantren will be more discriminated, disharmony and conflict will be formed, and further or apart from society. Because according to research results from Setara Institute (2012) that the number of followers of radical Islam group is increasing, the social segment of its followers are students and college students who do not work, the underlying factors become radical followers that is religious belief and economic injustice and pesantren is not as as a place of radical Islamic belief.

Thus it requires the media interaction between pesantren, community, government and higher learning through economic empowerment program, in order to prove pesantren is an educational institution that really bring benefit to all and can dismiss negative stigma. The pesantren can include Islamic economics lessons on Islamic entrepreneurship, sharia economy management and Sharia Cooperative in local content or additional lessons, in order to foster the spirit and competence in the field of economic business.

\subsection{Designing Economic Empowerment in Pesantren Education}

The inclusion course learning of economic empowerment in pesantren education and curriculum activities creates motivation and entrepreneurship skills that equip santri especially when they have graduated, creating jobs, prosperity and media interaction with the community. Even economic education activities and curricula can anticipate negative stigma against pesantren and strengthen harmony. Because pesantren according to Mursalin and Katsir (2010) and Rajab (2014) pesantren has curriculum with the lesson of fiqh, tafsir, and aqidah which is oriented toward understanding and religious attitude which is dogmatic and conservative, but can also be combined with demands of moderatism.

Based on the results of interviews and focused discussions that gave birth to ideas, concepts and commitments, thus a draft of empowerment can be made in the pesantren education process namely (1) Empowerment program implemented in participatory manner that involves all elements of boarding school starting from santri, parents of santri, ustadz and boarding board and alumni. So that the empowerment program can be in accordance with the interests, talents, potential and economic resources owned, both by students and boarding schools. In Darusy Syahadah Boyolali pesantren which has 1200 santri and the width of empowerment program and land that 4 hectare can be designed and agreed with santri that is horticultural agriculture especially vegetables and fruits, livestock farms to meet the Eid al-Adha and the development of Sharia Cooperatives become parent business pesantren. While the pesantren of Al Muttaqin Cirebon with fewer santri that is 103 and land that 1 hectare have interests, potentials and resources such as hydroponic cultivation and minimarket that is not only to meet the internal needs of the pesantren but also for external parties because it is located on the edge of the Cirebon highway to Kuningan;

(2) The empowerment program can be initiated as an extracurricular activity or addition of santri activities by establishing a santri organization, sharia cooperatives and horticulture and hydroponics cultivation groups. The process of forming oragnization exstraculiculer of santri first conducted empowerment activities in the form of counseling about motivation and increasing knowledge and insight of Muslim entrepreneurship, the formation of Sharia cooperatives and land use as a food force of pesantren. The counseling was conducted by using lecture and interactive dialogue, as the initial stage of the participants of the santri who have interest to be entrepreneurship managers as many as 10-15 people as pioneers and added ustadz who will become facilitator and become the board and recruit other students. The next stage of training is carried out as a continuation of extension activities by practicing the management of enerpreneurship and cooperatives such as management, membership, finance to the report. The practice of hiroponic cultivation, goats and horticulture can be done directly at the site of the cultivation. The next step is to provide continuous facilitation while monitoring and evaluating activities. Extension, practice, mentoring and money empowerment activities can be organized by involving government agencies, academics from universities and experienced alumni as practitioners, as well as non-governmental organizations as entrepreneurial or cooperative activists.

(3) Incorporating the material of economic empowerment, entrepreneurship, management of Islamic economy, and sharia cooperative into pesantren curriculum as the subjects of choice for santri accompanied by practicum program, apprenticeship and community service for graduates or alumni.

According to Yuli et al. (2011) pesantren can be an institution that prevents the existence of radicalism because it teaches morality and peace and tolerant cooperation. Maksum (2015), Abdurrachim (2016) and Latif (2016) says pesantren can adapt to the development of the times, into a modern educational system that teaches matter other 
than salaf through the education curriculum that will be able to form a tolerant, harmonized and multicultural education for santri.

The material is taught in the classroom at the end of the education year before graduation to provide knowledge, understanding, motivation and insight to the students ie concept, theory and development of economic empowerment, Islamic entrepreneurship, Islamic economic management and Sharia Cooperative. Learning media can be supported by impressions or samples of examples of pesantren model which have success in economic empowerment of santri, entrepreneur and pesantren cooperative in developing economic and welfare business for santri, pesantren, alumni and surrounding community. Then santri carries out practicum or apprenticeship in accordance with the interests and potential of students to choose the economic field, such as empowering students in the cultivation of horticultural agriculture (vegetables and fruits) both with conventional system and with hydroponics, then empowering the cultivation of livestock, cattle goat breeding and cattle, entrepreneurship in the field of retail in the form of stalls that provide daily needs, culinary food, restaurants, photo copy services, workshops, printing, promotional and marketing strategies. Furthermore Sharia cooperative is about management administration, finance, stewardship and membership and development strategy. The location of the practicum or apprenticeship can be place of business owned by the pesantren itself or if not yet existed, can be placed by cooperating on pesantren which has succeeded in empowering business, entrepreneurship, and Sharia Cooperative. The process of practicing or apprenticeship for students is carried out at least one month during the holiday period after students perform the evaluation of learning, so as not to disrupt the learning process. According to Hartono (2012); Yaqin (2012), Nurjaman (2013) and Fatkhuronji et al. (2015) pesantren can add workshop course learning or training in curiculum learning to improve the competence of santri.

(4) Conducting mentoring, monitoring and evaluation result of economic empowerment of students in the field of entrepreneurship and Cooperative through interviews with instructors and managing internships on apprenticeship of students, performing evaluation tests in writing for students to identify problems that are still faced, and motivation, and development of success by measuring knowledge, skills, and internship experience. Conducting interviews with santri on apprenticeship, evaluation and follow up activities to strengthen motivation, interest, talents and skills of entrepreneurship and Sharia Cooperative.

(5) The subject matter of empowering santri, enterpreneurship and Syariah cooperation is an additional subject for interested students and not mandatory subjects for every santri, so as not to degrade the Islamic lesson which has been characteristic. But if the result of the lessons and practicum or apprentices of empowering santri, entrepreneurship (Indra 2017) and Sharia Cooperative can become additional characteristics and attraction for pesantren such as agribusiness pesantren, entrepreneurship pesantren, and even become pesantren of information and technology (IT). Ife and Tesoriero (2006) emphasize that community empowerment will not eliminate local knowledge and wisdom from the community, but develops for greater power and wider usefulness. Carolina (2017) and Sarah (2017) suggest the pesantren could be allows for more access to technology devices and diverse resources to use technology for students earning efficiently.

Santri and pesantren may not only play a role besides religious education which emphasizes morality and religiosity but can also act as social and economic institution that form, develop and strengthen economic institution to create business field and improve the welfare of santri, pesantren and community. Falah (2016) states pesantren as an educational institution to establish piety both in terms of success of the hereafter, as well as the success of the world, thus santri and society can develop a life of rahmah, blessings and justice. Empowerment is very relevant to education, because both have the goal to provide motivation, knowledge and skills so as to have the power to get out of helplessness and be self-sufficient. According to Crabtree (2009), Maslani (2012) and Hayah (2017) one form of empowerment in the process of learning service is the opportunity given to participate and have the ability to dare to aspire and carry out activities in accordance with the potential and needs.

Santri and pesantren can openly interact with the surrounding community in particular, and the wider community in general so that the negative, closed, exclusive, fanatic stigma, religious and radical denials will be anticipated.

The peaceful concept of Islam, the blessing of all nature and the balance of world life and akherat can be implemented by implementing the program of empowering santri, entrepreneurship and Sharia Cooperative. Teachers, instructors and facilitators can be provided by pesantren by recruiting faculty and inviting experienced alumni, in collaboration with other advanced pesantren, government agencies and universities in economic, entrepreneurship and Sharia (Islamic) empowerment. According to Sulaiman et al. (2018) empowerment activities will be effective and successful if implemented by working together and synergize between government, business and civil society organizations in this case pesantren. Mantu (2015) affirms that one form of tackling and fighting against radicalism is to create and cultivate the established peace-building relationship between pesantren and the 
community. Ahyar (2015) states that deradicalization can be done through education that reinforces Islamic thought from various perspectives not just political but social and economic.

Based on the results and discussion, an empowerment model can be created in Figure 1.

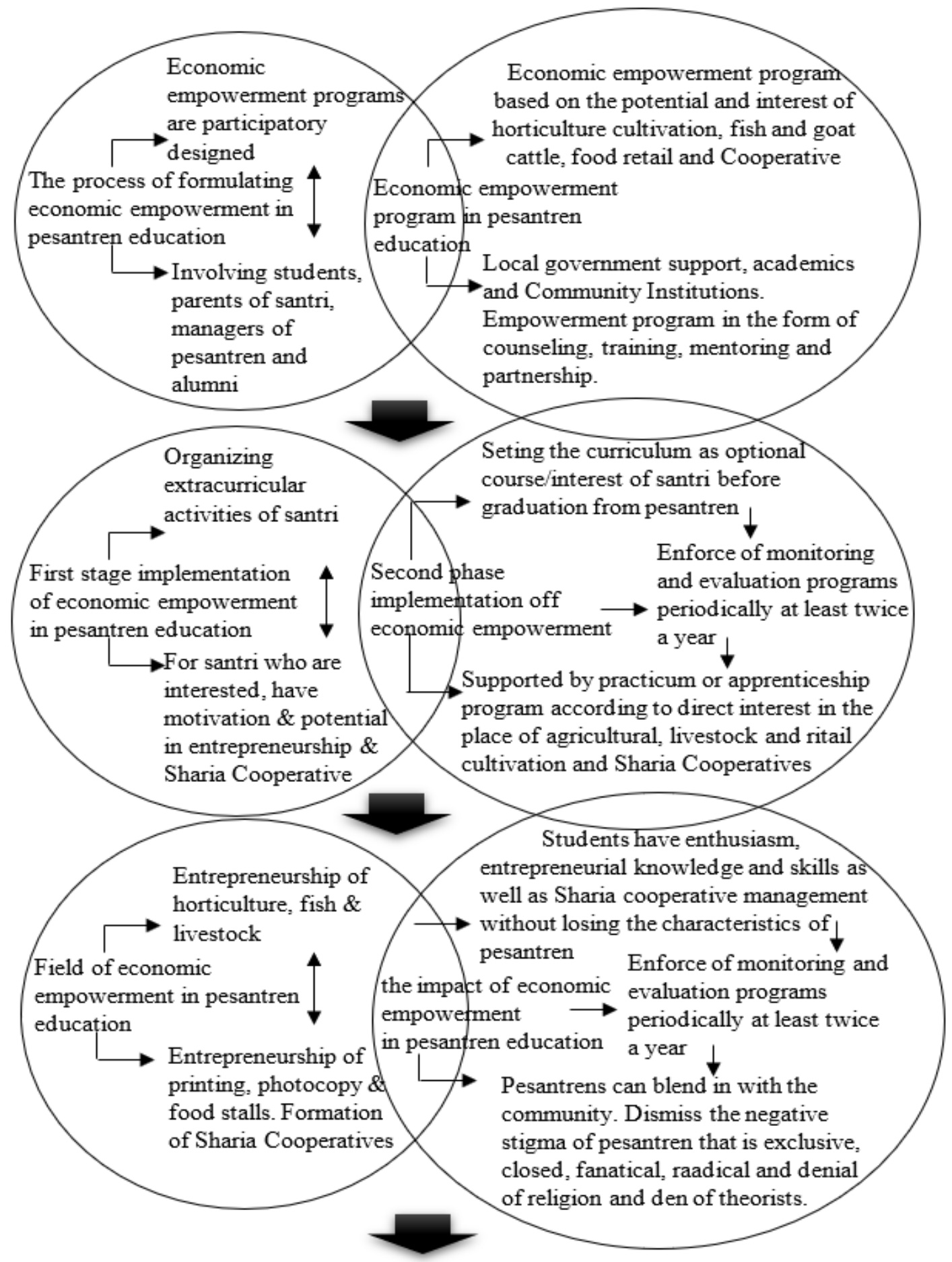

Enforce monitoring and evaluation of the empowerment program periodically once a year in a participatory and dialogical manner between pesantren owners, santri business groups, pesantren cooperative administrators, alumni and the community.

Pesantren as a religious education institution as well as socio-economic education institutions that can improve welfare for pesantren, santri and community

Figure 1. Model of economic empowerment of santri in pesantren education 


\section{Conclusion}

Pesantren could be creating a religious and social education institution as well as economic education institutions that implements the concept of a balance between the life of the world and akherat and become a mercy for the whole of nature.

Pesantren has the ability for design an economic empowerment program based on potential, interests and resources in a participatory manner by involving the students, parents of santri, alumni, ustadz and pesantren management.

Implementation of pesantren economic empowerment can cooperate with local government, college, social institution and other pesantren which have succeed in economic empowerment, entrepreneurship and Cooperative.

The relevant economic empowerment of pesantren according to the interests, potentials and resources through participatory dialogue process, namely the cultivation of horticulture and vegetables, the cultivation of fish and goat, the retail business that provides daily necessities, printing and the establishment of cooperatives as the parent business of pesantren economy .

The economic empowerment in pesantren can be carried out in two stages: (1) economic empowerment stage as a form of activity of extracurricular community service which is obligatory for the santri who will graduate or graduated periodically and continuously by cooperating with other parties outside pesantren. (2) The stage of economic empowerment in selected subjects activities or specialization in the curriculum of pesantren education, with theoretical and practical course learning or internships placed in the location of empowerment or entrepreneurship either in the pesantren itself or outside the pesantren in cooperation with other parties.

The economic empowerment of pesantren can be a job opportunity for santri and pesantren graduates, as well as an additional source of income for pesantren so as to improve their welfare and create economic independence. Then it can also be a medium of interaction with the community and other institutions to answer the negative stigma of pesantren which is considered exclusive, closed, fanatical and there is a denial of religion, and radical.

The economic empowerment program in pesantren education can produce graduates who are not only experts and act in the religious field, but also there are master in the economic field with the Islamic perspective for welfare by creating and developing entrepreneurship, self-reliance and realizing Islam as a mercy for all of nature..

\section{Acknowledgments}

We would like to thank for attention and support by Institute for Research and Community Service of Jenderal Soedirman University and Ministry of Research, Technology and Higher Education of the Republic of Indonesia, So that research could be well organized and useful for studies and implementation of research results for the community, boarding school, and stakeholders, as well as thanks to the Journal of International Educational Research (IER) for the support and publication of our research articles.

\section{References}

Abdullah, A. (2016). Gerakan Radikalisme dalam Islam: Perspektif Historis. Jurnal Addin, 10(1), 1-28, https://doi.org/10.21043/addin.v10i1.1127

Abdurrachim, R. F. H. (2016). Islamic Fundamentalist and National: Study at Darul Ma'rifat Islamic Boarding School, Kediri East Java. Islam Realitas: Journal of Islamic and Social Studies, 2(1), 34-44. https://doi.org/10.30983/islam_realitas.v2i1.113

Abdurrahman, N. H. (2016). Character Education in Islamic Boarding School Based SMA Amanah. Jurnal Pendidikan Islam. 2(2), 287-305. https://doi.org/10.15575/jpi.v2i2.791.g683

Adams, R. (2003). Social Work and Empowerment. 3rd ed. New York: Palgrave Macmillan.

Ahyar, M. (2015). Membaca Gerakan Islam Radikal dan Deradikalisasi Gerakan Islam. Walisongo, 23(1), 1-26. https://doi.org/10.21580/ws.23.1.220

Alfanani, T. S. (2016). Konstruksi Sosial Komunitas Pesantren mengenai Isu Radikalisme (Studi Kasus Pada Pesantren Salaf \& Modern di Kota Malang). Jurnal Sosiologi Agama, 10(2), 1-24. https://doi.org/10.14421/jsa.2016.102-01

Arfiansyah., \& Riza, M. (2016). Dampak Peraturan Gubernur Aceh Nomor 451.2/474/2003 terhadap Peningkatan Kualitas Pendidikan Dayah, 15(2), 177-212.

Asrori, A. (2015). Radikalisme di Indonesia: antara Historisitas dan Antropisitas. Kalam: Jurnal Studi Agama dan Pemikiran Islam, 9(2), 253-268. https://doi.org/10.24042/klm.v9i2.331

Aswirna, P. (2013). Small and Medium Industry for Sustaining Madrasa in Global Change : Study at Darul Ma'rifat 
Modern Islamic Boarding School in East Java. Jurnal Al-Ta'lim, 1(6), 506-523.

Azra, A. (1999). Islam Reformis: Dinamika Intelektual dan Gerakan. Jakarta: Raja Grafindo Persada.

Cahyadi, R.A.H., (2017). Pengembangan Pondok Pesantren. Halaqa: Islamic Education Journal, 1(1), 43-52. https://doi.org/10.21070/halaqa.v1i1.820

Carolina, E. S. (2017). Are Islamic Boarding Schools Ready? The Use of the Computer-Based Test in the National Exam Policy for English Subject. Ta'dib: Journal of Islamic Education, 22(2), 44-53.

Crabtree, R.D. (2009). Mutual empowerment in cross-cultural participatory development and service learning: Lessons in communication and social justice from projects in El Salvador and Nicaragua. Journal of Applied Communication Research, 26(2), 182-209, https://doi.org/10.1080/00909889809365501

Das, W. H., Halik, A., \& Amaluddin (2016). Paradigm of Islamic Education in the Future: The Integration of Islamic Boarding School and Favorite School. Information Management and Business Review, 8(4), 24-32

Fajarini, U. (2014). Peranan Kearifan Lokal dalam Pendidikan Karakter. Sosio Didaktika, 1(2), $123-130$. https://doi.org/10.15408/sd.v1i2.1225

Falah, R. Z. (2016). Membentuk Kesalehan Individual dan Sosial Melalui Konseling Multikultural. Konseling Religi: Jurnal Bimbingan Konseling Islam, 7(1), 163-188. https://doi.org/10.21043/kr.v7i1

Fatkhuronji, M., Ekosiswoyo, R., \& Raharjo, T. J. (2015). Life skills education training for santri in islamic boarding school. The Journal of Educational Development, 3(2), 106-114

Hadiningrum, L.P. 2017. Islamic Education Reconstruction: Mastery Learning Based in Modern Islamic Boarding School. HUNAFA: Jurnal Studia Islamika, 14(1), 1-15. https://doi.org/10.24239/jsi.v14i1.458.1-15

Hamdani (2012). Bimbingan dan Penyuluhan. Bandung: Pustaka Setia.

Hartono, D. (2012). Pengembangan Manajemen Pondok Pesantren di Era Globalisasi. Surabaya: Ponpes Jagad Alimusssiry.

Hayah, R.K. (2017). Character Education in Islamic Boarding School and The Implication to Students' Attitude and Critical Thinking Skills on Biodiversity Learning. Journal of Physics: Conf. Series. IOP Publishing, 1-7. https://doi.org/10.1088/1742-6596/812/1/012101

Hidayat, M. (2016). Model Komunikasi Kyai dengan Santri di Pesantren. Jurnal Komunikasi ASPIKOM, 2(6), 385-395. https://doi.org/10.24329/aspikom.v2i6.89

Hidayat, N. (2016). The Implementation of Character Education Model at Islamic Boarding School of Pabelan, Magelang, Central Java. Jurnal Pendidikan Islam, 5(2), 431-455. https://doi.org/10.14421/jpi.2016.52. 431455

Ife, J., \& Tesoriero, F. (2006). Community Development: Community Based Alternatives in an Age of Globalisation. Australia: Person Education.

Ikhwan, A. (2017). Development of Quality Management Islamic Education in Islamic Boarding School (Case Study Madrasah Aliyah Ash Sholihin). Al-Hayat: Journal of Islamic Education, 1(1), 91-177.

Indra, H. (2017). Salafiyah Curriculum at Islamic Boarding School in The Globalization Era. Tarbiya: Journal of Education in Muslim Society, 4(1), 74-88.

Isnaini, M. (2013). Internalisasi Niali- Nilai Budaya Pendidikan Karakter Di Madrasah. Jurnal Al-Ta'lim, 1(6), 445-450. https://doi.org/10.15548/jt.v20i3.41

Kusnadi, E., Sobur, K., \& Aziz, A. (2017). An Islamic Boarding School: A Study Of Al-Mubarok Al-Islam Within The Social Changes Of Seberang Kota Jambi. Addin: Media Dialektika Ilmu Islam, 11(1), 101-130. https://doi.org/10.21043/addin.v11i1.1920

Latif, M. (2016). Multicultural Education in Islamic Boarding School: A Descriptive Study of Pesantren DDI Mangkoso, South Sulawesi. JICZA Journal of Islamic Civilization in Southeast Asia, 5(2), 231-250. https://doi.org/10.24252/jicsa.v5i2.2351.g2280

Maksum, A. (2015). Model Pendidikan Toleransi Di Pesantren Modern Dan Salaf. Jurnal Pendidikan Agama Islam, 3(1), 84-108. https://doi.org/10.15642/jpai.2015.3.1.81-108

Mantu, R. (2015). Bina-Damai dalam Komunitas Pesantren: Sebuah Upaya Counter-Radikalisme. Jurnal Walisongo, 23(1), 131-150. https://doi.org/10.21580/ws.23.1.227

Maslani (2012). Multicultural-Based Education in the Islamic Boarding School. Advances in Natural and Applied 
Sciences, 6(7), 1109-1115.

Meylaz, S. (2014). Pelaksanaan Integrasi Pesantren Salaf dan Khalaf di Pondok Pesantren Qotrun Nada. Skripsi. UIN Syarif Hidayatullah Jakarta.

Mikkelsen, B. (2011). Metode Penelitian Partisipatoris dan Upaya Pemberdayaan, Penerjemah: Matheos Nalle. Jakarta : Yayasan Pustaka Obor Indonesia Mursalin, A., \& Katsir, I. 2010. Pola Pendidikan Keagamaan Pesantren dan Radikalisme: Studi Kasus Pesantrenpesantren di Provinsi Jambi. Kontekstualita, 25(2), 255290.

Muharom, F. (2015). Respons Pondok Pesanten terhadap Problem Pencitraan di Media: Studi Pemulihan Citra Pondok Pesantren Islam Al-Mukmin Ngruki Sukoharjo Surakarta. Disertasi. UIN Sunankali Jaga Yogyakarta.

Muklasin (2016). Manajemen Pendidikan Karakter Santri: Studi Kualitatif di Pondok Pesantren Bahrul Ulum Margodadi Kecamatan Sumberejo Kabupaten Tanggamus. Tesis. Universitas Lampung.

Mumtahanah, N. (2015). Pengembangan Sistem Pendidikan Pesantren dalam Meningkatkan Profesionalisme Santri. Al-Hikmah Jurnal Studi Keislaman, 5(1), 54-70.

Mursalin, A., \& Katsir, I. (2010). Pola Pendidikan Keagamaan Pesantren dan Radikalisme: Studi Kasus PesantrenPesantren di Provinsi Jambi. Kontekstualita, 25(2), 255-290.

Nilan, P. (2009). The 'spirit of education' in Indonesian Pesantren. Journal British Journal of Sociology of Education, 30(2), 219-232. https://doi.org/10.1080/01425690802700321

Nurjaman, I. (2013). English Learning System in Islamic Boarding School. Jurnal Pendidikan Islam, 28(3), 499516. https://doi.org/10.15575/jpi.v28i3.561

Perdana, N. S. (2015). Character Education Model Based on Education in Islamic Boarding School. Edutech Journal Educational Technology, 14(3), 402-422. https://doi.org/10.17509/edutech.v14i3.1387.g965

Purnamasari, N. I. (2016). Konstruksi Sistem Pendidikan Pesantren Tradisional di Era Global: Paradoks dan Relevansi. El-Banat: Jurnal Pemikiran dan Pendidikan Islam, 6(2), 194-212.

Rahmawati, R. F. (2016). Konseling Budaya Pesantren : studi deskriptif terhadap Pelayanan Bimbingan Konseling Bagi santri Baru. Konseling Religi: Jurnal Bimbingan Konseling Islam. 7(1), 61-84. https://doi.org/10.21043/kr.v7i1.1359

Rajab, K. (2014). Methodology of Islamic psychotherapy in Islamic boarding school Suryalaya Tasikmalaya. IJIMS: Indonesian Journal of Islam and Muslim Societies, 4(2), 257-289. https://doi.org/10.18326/ijims.v4i2.257-289

Rodin, D. (2016). Islam dan Radikalisme: Telaah atas Ayat-ayat “Kekerasan” dalam al-Qur'an. Jurnal Addin. 10(1), 29-60. https://doi.org/10.21043/addin.v10i1.1128

Sarah, S. F. (2017). Understanding Students' Perspective and Use of Technology for Language Learning at Islamic Boarding School. European Journal of Language and Literature, 3(2), 59-65. https://doi.org/10.26417/ejls.v8i1.p59-65

Servaes, J. (1999). Communication for Development: One World, Multiple Cultures. Cresskill NJ: Hampton Press

Setara Institute. (2012). Dari Radikalisme Menuju Terorisme: Studi Relasi dan Transformasi Organisasi Islam Radikal di Jawa Tengah dan DI Yogyakarta. Hasani, I., \& Naipospos, B.T. Jakarta: Pustaka Masyarakat Setara

Suhartini, A., Imam, H., Khambali., \& Basyid, A. (2005). Model-Model Pemberdayaan Masyarakat. Yogyakarta: Pustaka Pesantren.

Sulaiman, A. I., Chusmeru., \& Masrukin (2018). Strategy of Cooperative Islamic Boarding School as Economic Empowerment Community. Inferensi: Jurnal Penelitian Sosial Keagamaan. 12(1), 25-44. https://doi.org/10.18326/infs13.v12i1.25-44

Susmono, J., \& Hidayat, B. (2010). Buku Panduan - Pemberdayaan Masyarakat dengan Pelibatan Jender dan Kemiskinan dalam Pembangunan Sanitasi. Jakarta: Tim Teknis Pembangunan Sanitasi (TTPS) Bappenas.

Syahyuti, (2006). Tiga Puluh Konsep Penting dalam Pembangunan Pedesaan dan Pertanian, Jakarta: Bina Rena Pariwara.

Thahir, M. (2014). The Role and Function of Islamic Boarding School: An Indonesian Context. Tawarikh: International Journal for Historical Studies, 5(2), 197-208.

Thoyyib, M. (2018). Radikalisme Islam. Ta’lim: Jurnal Studi Pendidikan Islam, 1(1), 90-105. 
Yaqin, H. (2012). Islamic Boarding School Curriculum in Indonesia: A Case Study in Islamic Boarding Shool in South Kalimantan. Jurnal Al-Hikmah, 13(1), 18-38.

Yuli, N. G., Haningsih, S., \& Adikrishna, R. (2011). The Common Room Design of Islamic Boarding School: A Preliminary Research in Yogyakarta Islamic Boarding School. International Journal of Engineering \& Technology IJET-IJENS, 11(4), 127-134.

\section{Copyrights}

Copyright for this article is retained by the author(s), with first publication rights granted to the journal.

This is an open-access article distributed under the terms and conditions of the Creative Commons Attribution license (http://creativecommons.org/licenses/by/4.0/). 